\title{
Effects of gamma radiation in therapeutic dose on the chemical characteristics of a
}

\section{polycaprolactone/ZnO nanocomposite}

\author{
Efeitos da radiação gama em dose terapêutica nas características químicas do nanocompósito \\ policaprolactona/ZnO
}

Efectos de la radiación gamma en dosis terapéutica sobre las características químicas del nanocompuesto policaprolactona/ZnO

Received: 09/13/2021 | Reviewed: 09/19/2021 | Accept: 09/25/2021| Published: 09/26/2021

\author{
Marcos Vinícius da Silva Paula \\ ORCID: https://orcid.org/0000-0001-9764-9049 \\ Universidade Federal do Pará, Brazil \\ E-mail: mpaula@ufpa.br \\ Severino Alves Junior \\ ORCID: https://orcid.org/0000-0002-8092-4224 \\ Universidade Federal de Pernambuco, Brazil \\ E-mail: juniorbstr@gmail.com
}

\begin{abstract}
In this investigation, the influence of gamma radiation in a therapeutic dose, such as the dose generally administered (on average) in two cycles of radiotherapy treatment, was evaluated for the chemical characteristics of nanocomposite films formed by polycaprolactone (PCL) with oxide nanoparticles of $\mathrm{ZnO}$ ( $\mathrm{ZnO}$ NPs). The PCL nanocomposite films with ZnO NPs (PCL/ZnO NCs) were obtained via solvent casting method, using chloroform as solvent, with ZnO NPs mass contents in relation to polymer masses equal to: $02 \% ; 0.4 \% ; 0.6 \% ; 0.8 \%$ and $1.0 \%$. After this step, the films obtained were exposed to gamma radiation in a dose of $140 \mathrm{~Gy}$ in the presence of air and at room temperature. The influence of gamma radiation in a therapeutic dose on the chemical characteristics of nanocomposite films obtained through the solvent casting method, was accessed through absorption spectroscopy in the infrared region. Our results indicate that the chemical structure of PCL is preserved after exposure to gamma radiation at $140 \mathrm{~Gy}$.
\end{abstract}

Keywords: Gamma radiation; Polycaprolactone; $\mathrm{ZnO}$ nanoparticles.

\section{Resumo}

Nesta investigação, a influencia da radiação gama em dose terapeutica, como por exemplo, a dose costumeiramente utilizada (em media) em dois ciclos de tratamento radioterápico, foi avaliada sobre as características químicas de filmes de nanocompósitos formados pela policaprolactona (PCL) com nanopartículas de óxido de ZnO (ZnO NPs). Os filmes de nancompósitos da PCL com ZnO NPs (PCL/ZnO NCs) foram obtidos através do método de solvent casting, utilizando clorofórmio como solvent, com teores em masa de ZnO NPs em relação a massa do polímero iguais a: $02 \% ; 0.4 \%$; $0.6 \% ; 0.8 \%$ e $1.0 \%$. Apos essa etapa os filmes obtidos foram expostos a radiação gama na dose de 140 Gy em presenca de ar e em temperatura ambiente. A influência da radiação gama em dose terapeutica nas caracterísiticas químicas dos filmes de nanocompósitos obtidos através do médoto de solvent casting, foi acessada através da espectroscopia de absorção na região do infravermelho. Nossos resultados indicam que a estrutura química da PCL é preservada após a exposição a radiação gama em 140 Gy.

Palavras-chave: Radiação gama; Policaprolactona; Nanopartículas de $\mathrm{ZnO}$.

\section{Resumen}

En esta investigación se evaluó la influencia de la radiación gamma sobre la dosis terapéutica, como la dosis habitualmente utilizada (en promedio) en dos ciclos de tratamiento de radioterapia, sobre las características químicas de películas de nanocompuestos formadas por policaprolactona (PCL) con nanopartículas de óxido de ZnO (NP de $\mathrm{ZnO}$ ). Las películas de nanocompuestos de PCL con NP de ZnO (PCL / ZnO NC) se obtuvieron mediante el método de fundición por solvente, utilizando cloroformo como solvente, con contenidos de masa de ZnO NP en relación a la masa de polímero igual a: $02 \% ; 0,4 \% ; 0,6 \% ; 0,8 \%$ y 1,0\%. Tras este paso, las películas obtenidas se expusieron a radiación gamma a una dosis de 140 Gy en presencia de aire y a temperatura ambiente. Se accedió a la influencia de la radiación gamma en dosis terapéutica sobre las características químicas de películas de nanocompuestos obtenidas mediante el método de fundición con solvente, mediante espectroscopía de absorción en la región infrarroja. Nuestros resultados indican que la estructura química del PCL se conserva después de la exposición a radiación gamma a 140 Gy.

Palabras clave: Radiación gamma; Policaprolactona; Nanopartículas de ZnO. 


\section{Introduction}

Polycaprolactone (PCL) is a semi-crystalline, thermoplastic, biocompatible, biodegradable polymer, with hexanoate as a repeating unit (Labet \& Thielemans, 2009; Woodruff \& Hutmacher, 2010). Polycaprolactone is widely used in tissue engineering (Dwivedi et al., 2020), drug delivery (Chang et al., 2018), implants (Stewart et al., 2020) and in the food packaging sector (Lyu et al., 2019). For some biomedical applications and in the food packaging sector, however, polycaprolactone does not have satisfactory thermal, mechanical and antibimicrobial activity properties (Lopez-Figueras et al., 2017). An alternative for the absence of these characteristics would be the addition of nanoparticles (NPs) to the PCL matrix forming a material called nanocomposite (Das et al., 2018).

Among the nanoparticles that can be added to the PCL matrix are the ZnO oxide nanoparticles(Mallakpour \& Behranvand, 2016). $\mathrm{ZnO}$ oxide is a biocompatible, semiconductor agent with antibimicrobial properties (Augustine et al., 2014; Augustine et al., 2016). ZnO has been used for diverse applications in different polymers (Elen et al., 2012). Among the applications that have been proposed for the nanocomposite formed by PCL with ZnO NPs, is its use in implants (Mallakpour \& Nouruzi, 2016). The use of nanocomposites in implants in areas close to regions that are exposed to radiotherapy treatment, however, may compromise their properties, contributing to the degradation of the polymer matrix (Cooke \& Whittington, 2016).

Radiotherapy treatment can reach a total dose of $70 \mathrm{~Gy}$, through fractionation of the total dose (Cooke \& Whittington, 2016; Pereira-Loch et al., 2011). Most investigations carried out on the effect of gamma radiation on the thermal, physical, morphological and chemical characteristics of polymeric nanocomposites use high doses of gamma radiation as is the case with the $25 \mathrm{kGy}$ dose (Paula et al, 2019). Few studies have been carried out on the effects of gamma radiation at therapeutic doses on a polymeric nanocomposites (Cooke \& Whittington, 2016). Gamma radiation can cause the phenomenon of chain scission, crosslinking and hydrolysis in polymers (Silva et al, 2013). The effects of gamma radiation on polymers depend on the applied dose, dose rate, radiation exposure conditions and polymer structure (Silva et al., 2013).

Thus, the objective of this investigation was to evaluate the effects of gamma radiation in a therapeutic dose on the chemical characteristics of PCL/ZnO NCs films. This corresponds to two cycles of radiotherapy treatment, which is equivalent to a total dose of $140 \mathrm{~Gy}$ on average. The films were obtained by the solvent evaporation method and exposed to gamma radiation at $140 \mathrm{~Gy}$ and further characterized using experimental techniques.

\section{Methodology}

\subsection{Materials}

All the reagents used were analytical grade and used as received. Nanosized ZnO powder was acquired from Aldrich with particle size $<100 \mathrm{~nm}$. PCL was obtained from Capa ${ }^{\mathrm{TM}}$ (PCL 6500). Chloroform was purchased from Dinâmica.

\subsection{Preparation of nanocomposite films}

$\mathrm{ZnO}$ nanoparticles were added to $1 \mathrm{~mL}$ of chloroform and exposed to an ultrasonic bath for 30 minutes, after which the nanoparticle suspension and 2.5 grams of PCL were added in $50 \mathrm{ml}$ of chloroform and stirred for 24 hours. The nanocomposite films (PCL/ZnO NCs) were obtained through the evaporation of chloroform at room temperature for 48 hours. After this step, the films were dried under vacuum to eliminate residual chloroform. The NPs used to obtain the films were used at concentrations of of $0.2 \% ; 0.4 \% ; 0.6 \% ; 0.8 \%$ and $1 \%$ in relation to the polymer mass. 


\subsection{Methods and Analysis}

\subsubsection{Irradiation of samples}

All samples were exposed to gamma radiation from a source of ${ }^{60}$ Cobalt (Gammacell GC220 Excel irradiator - MDS Nordion, Canada) at a dose of $140 \mathrm{~Gy}$ (rate of $2.515 \mathrm{kGy} \mathrm{h}^{-1}$ ), in the presence of air at room temperature.

\subsubsection{Fourier Transform Infrared Spectroscopy}

The absorption spectra in the infrared region by attenuated total reflectance, were obtained at room temperature in a PerkinElmer Spectrum 400 Bruker spectrophotometer FT-IR / FT-NIR. Spectra were obtained with a resolution of $4 \mathrm{~cm}^{-1}, 32$ scans and a wave number between $4000 \mathrm{~cm}^{-1}$ and $510 \mathrm{~cm}^{-1}$. Analyses were performed in the attenuated total reflectance mode by direct analysis of samples on ZnSe crystal.

\subsubsection{X-ray diffraction}

The diffraction patterns were acquired on a Shimadzu X-ray diffractometer model XRD $-6000, \mathrm{Cu}-\mathrm{K} \alpha$ radiation $=$ $1.54056 \AA$, with a step of $0.02^{\circ}$, acquisition time of 1 second.

\subsubsection{Differential Scanning Calorimetry}

Heat flow curves were carried out in a differential scanning calorimeter, model 1 Star* system (Mettler Toledo) under a nitrogen atmosphere with the following steps: 1$) 0{ }^{\circ} \mathrm{C}$ to $80{ }^{\circ} \mathrm{C}$, at a rate of $10{ }^{\circ} \mathrm{C} \mathrm{min}^{-1}$; 2) cooling to $0{ }^{\circ} \mathrm{C}$, at a rate of $20{ }^{\circ} \mathrm{C}$ $\min ^{-1}$; and 3) $0{ }^{\circ} \mathrm{C}$ to $80{ }^{\circ} \mathrm{C}$, at a rate of $10{ }^{\circ} \mathrm{C} \min ^{-1}$ (Elen et al., 2012). The degree of crystallinity $\mathrm{X}_{\mathrm{c}}$ of the films was determined based on the equation: $X_{e}=\frac{\Delta H_{m}}{\Delta H_{m i n}^{\mathrm{m}}}$, where $\Delta H_{\mathrm{m}}^{0}$, equals the heat needed for a melting temperature for $100 \%$ crystalline PCL. The value used for the heat of fusion of the fully crystalline polymer was $139.3 \mathrm{~g} \mathrm{~g}^{-1}$ (Mattioli-Belmonte et al., 2012).

\subsubsection{Scanning Electron Microscopy (SEM)}

The samples were prepared on carbon tape on an aluminum support and coated with a 10-20 nm gold film, using a Bal-Tec SCD 050 sputter coater. Images were recorded by a scanning electron microscope (Tescan Mira3) operating at a voltage of $10 \mathrm{kV}$.

\subsubsection{Transmission Electronic Microscopy (TEM)}

TEM images for the NC films were obtained using a transmission electron microscope (Jeol, model JEM-2100), with $200 \mathrm{kV}$ accelerating voltage. Drops of the NC films suspended in dichloromethane were deposited on copper grids, with slow evaporation of the solvent.

\section{Results and Discussion}

\subsection{Preparation of nanocomposite films}

The PCL/ZnO NCs films with different percentages by mass of ZnO NPs, exhibiting a whitish color, were obtained through the solvent casting method as shown in Figure 1and then irradiated at $140 \mathrm{~Gy}$. The morphological and structural characterization and effects of gamma radiation in a therapeutic dose on the chemical characteristics of the obtained films will be detailed in the next sections. 
Figure 1. PCL/ZnO 1\% NC.

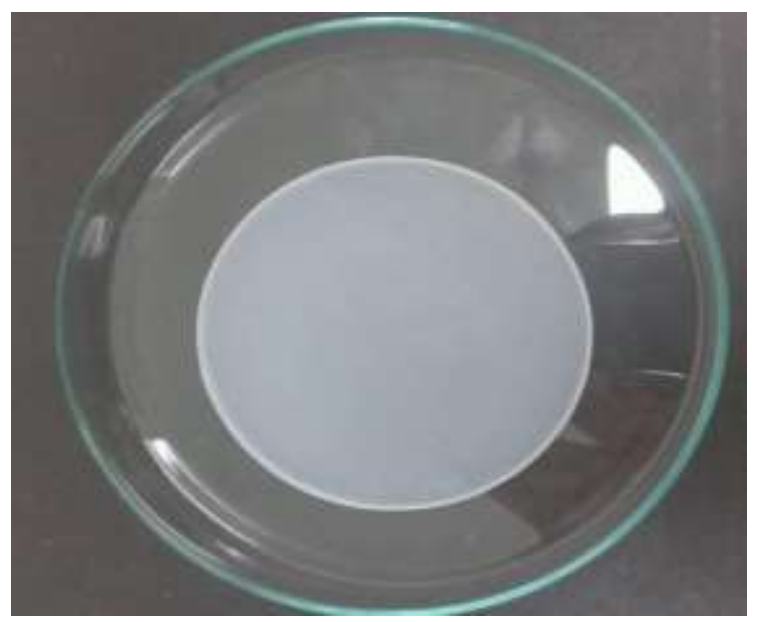

Source: Authors.

\subsection{FT-IR analysis of NCs}

FT-IR spectroscopy was used to evaluate structure, radiation effects and the interaction between ZnO NPs and PCL. Figures $\mathrm{X}$ and $\mathrm{Y}$ show the spectrum for pure PCL, PCL/ZnO NCs and irradiated PCL/ZnO NCs. In the spectrum of polycaprolactone a peak at $1725 \mathrm{~cm}^{-1}$ is observed, referring to the $\mathrm{C}=\mathrm{O}$ stretch of the polymer, the peaks at 2860 and $2950 \mathrm{~cm}^{-1}$ are attributed to the C-H bond of the polymer chain (Forster et al, 2015) (Figure 2). The samples from NCs and PCL presented practically the same spectrum (Figure 2). The same results were observed in the samples of PCL/ZnO NCs irradiated at 140 Gy (Figure 3).

Figure 2. FT-IR spectra of (a) PCL ;(b) PCL/ZnO 0.2\%; (c) PCL/ZnO 0.4\%; (d) PCL/ZnO 0.6\%; (e) PCL/ZnO 0.8\%; (f) PCL/ZnO 1\%.

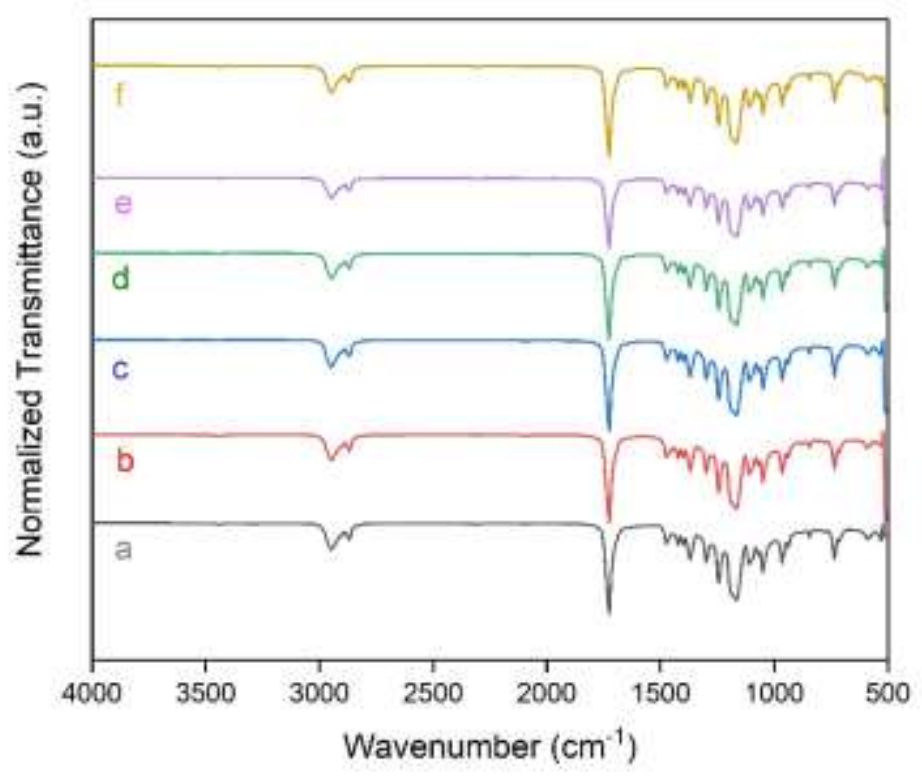

Source: Authors.

The results for PCL and NCs before and after irradiation is in agreement with what was observed by Cooke and 
Whittington, where they verified the non-displacement of the $\mathrm{C}=\mathrm{O}$ stretch for samples of scaffolds formed by PCL , that had been stored in PBS solution and then irradiated to 50 Gy on a linear accelerator (Cooke \& Whittington, 2016). Mallakpour et al., on the other hand, reported that after the addition of $2 \% \mathrm{ZnO} \mathrm{NPs}$, there was a shift in the peak of the $\mathrm{C}=\mathrm{O}$ stretch to regions of lower energy, indicating an interaction formed between the carbonyl group and zinc(Mallakpour \& Nouruzi, 2016). This physical interaction weakens the $\mathrm{C}=\mathrm{O}$ bond, resulting in the shift to a region of lower energy. This shift could not be observed in our investigation because the NCs obtained had up to $1 \% \mathrm{ZnO}$ NPs. These results indicated that the chemical structure of PCL is maintained after irradiation at $140 \mathrm{~Gy}$.

Figure 3. FT-IR spectra of (a) PCL-140 Gy; (b) PCL/ZnO 0.2\%-140 Gy; (c) PCL/ZnO 0.4\%-140 Gy; (d) PCL/ZnO 0.6\%-140 Gy; (e) PCL/ZnO 0.8\%-140 Gy; (f) PCL/ZnO 1\%-140 Gy.

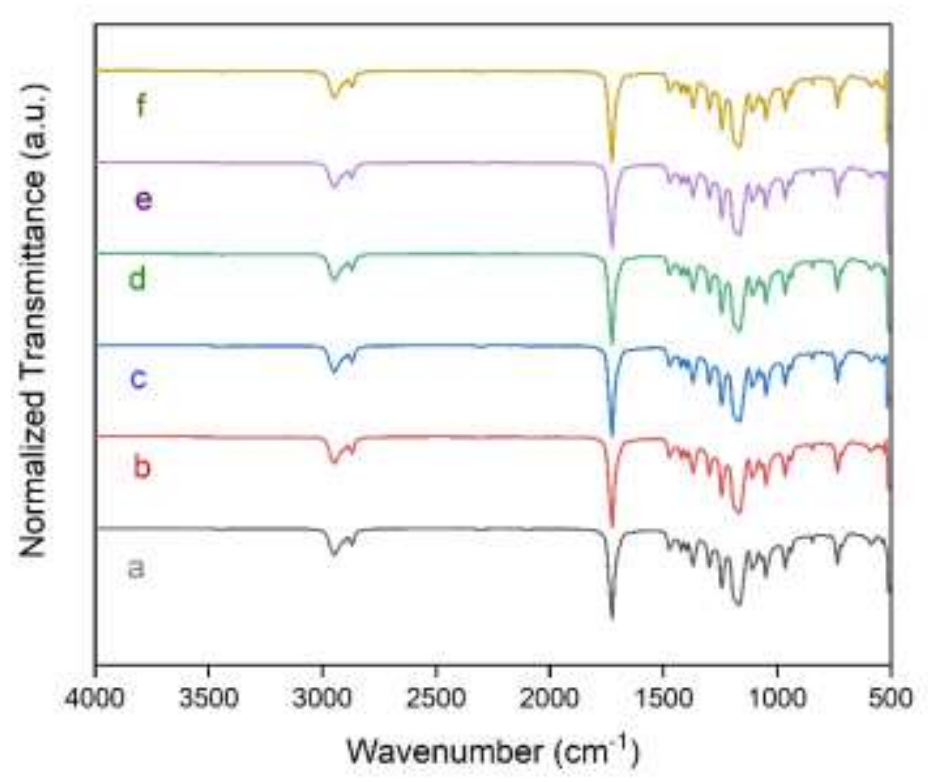

Source: Authors.

\subsection{X-ray diffraction patterns}

X-ray diffraction was used to evaluate the crystal profile of the PCL and PCL/ZnO Ncs samples. Figure 4 shows the diffractograms for pure PCL, ZnO NPs and PCL/ZnO NCs with different ZnO NPs contents. The polymer alone has three distinct reflection angles at 21.5; 22 and $23.8^{\circ}$, which are assigned to the planes (110), (111) and (200) of the orthorhombic structure of the polymer (Augustine et al., 2014). While the diffractogram for ZnO NPs presents the characteristic crystalline behavior of $\mathrm{ZnO}$ (Augustine et al., 2014). The obtained diffractograms showed the characteristic profile of PCL in all NCs evaluated (Figure 4). The peaks attributed to ZnO NPs were observed at low intensity in samples with ZnO NPs contents ranging from $0.4 \%$ to $0.8 \%$. This may be due to the low concentration of NPs, resulting in the suppression of $\mathrm{ZnO}$ diffraction (Augustine et al., 2014). 
Figure 4. XRD pattern of (a) PCL; (b) PCL/ZnO 0.2\%; (c) PCL/ZnO 0.4\%; (d) PCL/ZnO 0.6\%; (e) PCL/ZnO 0.8\%; (f) ZnO NPs.

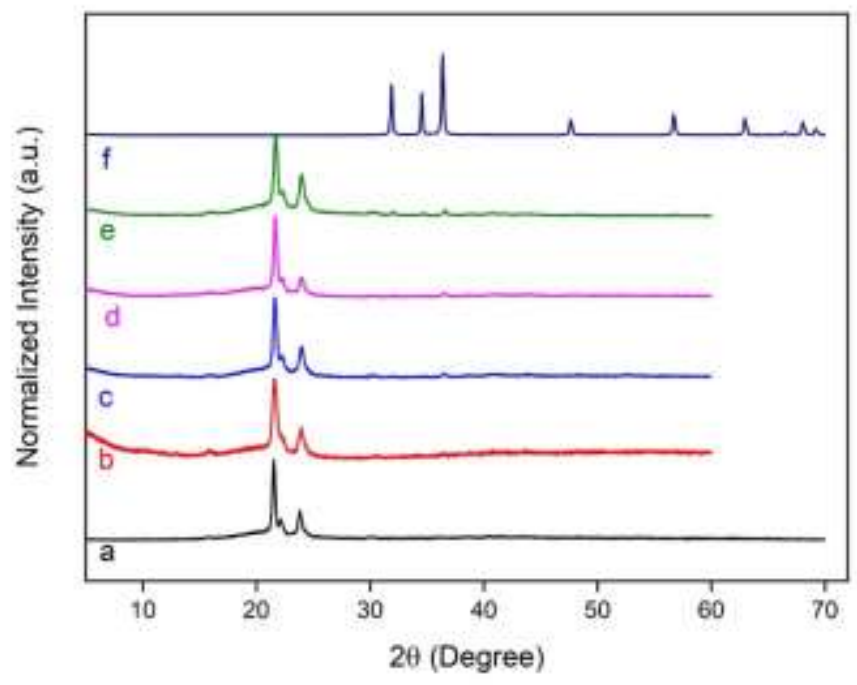

Source: Authors.

\subsection{Differential Scanning Calorimetry}

The quantification of polymer crystallinity for samples PCL, PCL/ZnO NCs with different levels of ZnO NPs was evaluated by the DSC technique. Table 1 summarizes the results of the DSC measurements. The melting temperature for the polymer is was expected (Labet \& Thielemans, 2009). The polymer melting temperature increased slightly to $62.4{ }^{\circ} \mathrm{C}$ with the addition of $0.2 \% \mathrm{ZnO}$ NPs. However, the addition of more material caused a decrease in the polymer melting temperature. The crystallinity content of the evaluated NCs showed marginal variations compared to the crystallinity content of PCL.

Table 1. Melting point temperature, crystallization temperature, enthalpy of melting and percentage of crystallinity for PCL and PCL/ZnO NCs films.

\begin{tabular}{llll}
\hline Sample & $\mathbf{T}_{\mathbf{m}}\left({ }^{\circ} \mathbf{C}\right)$ & $\Delta \mathbf{H}_{\mathbf{m}}(\mathbf{J} / \mathbf{g})$ & $\mathbf{X}_{\mathbf{c}}(\boldsymbol{\%})$ \\
\hline PCL & 61.7 & 45.0 & 32.3 \\
PCL ZnO 0.2\% & 62.4 & 54.1 & 38.8 \\
PCL ZnO 0.4\% & 61,7 & 48.2 & 34.6 \\
PCL ZnO 0.6\% & 59.8 & 50.0 & 35.8 \\
PCL ZnO 0.8\% & 61.8 & 47.3 & 33.9 \\
PCL ZnO 1.0\% & 59.1 & 40.8 & 29.2 \\
\hline
\end{tabular}

Source: Authors.

\subsection{Scanning Electron Microscopy}

The distribution of $\mathrm{ZnO} \mathrm{Nps}$ in the polymer matrix was evaluated by scanning electron microscopy. Figure 5a-c shows the distribution of different levels of ZnO NPs in the NCs. Considering that the homogeneous distribution of an inorganic agent in a polymeric matrix is not easily obtained, the situation is accentuated when using nanoparticles because they can aggregate, due to their high surface energy (Lepot et al., 2010). According to the images in Figure 5, a good dispersion of 
the nanoparticles in the polymer was obtained, without the need for the addition of surface modifying agents. These results are in agreement with those obtained by Elen and co-workers (Elen et al., 2012).

Figure 5. SEM image of (a) PCL/ZnO 0.2\%; (b) PCL/ZnO 0.6\%; (c) PCL/ZnO 1.0\%.

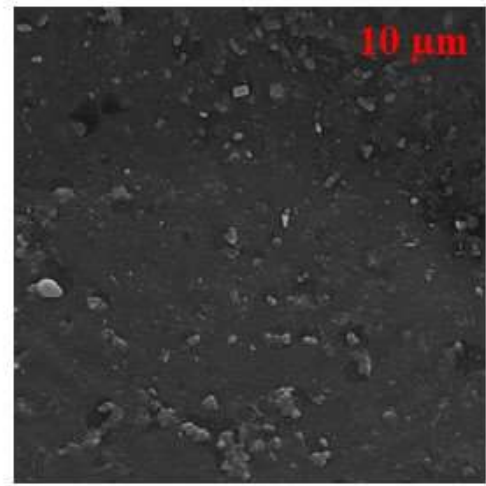

a)

$\mathrm{PCL} / \mathrm{ZnO} 0.2$

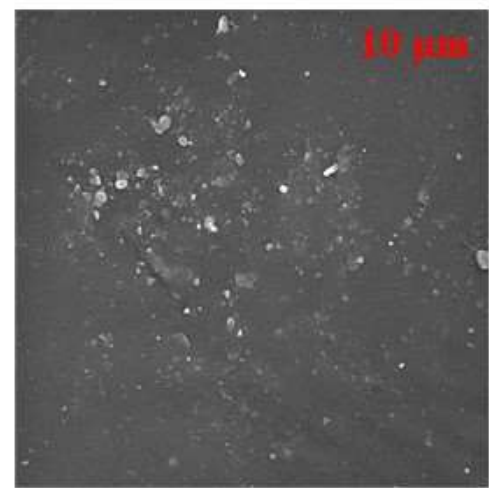

b)

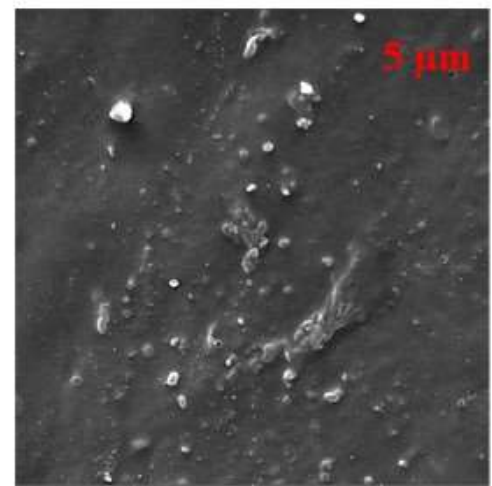

c)

PCL/ZnO 0.6

$\mathrm{PCL} / \mathrm{ZnO} 1.0$

\subsection{Transmission Electron Microscopy}

The morphology of the ZnO NPs was evaluated using images acquired by TEM. Figure 6 showed that the ZnO NPs, used in our investigation, are in nanometric dimensions and exhibit varied morphology.

Figure 6. TEM image of $\mathrm{ZnO}$ NPs.

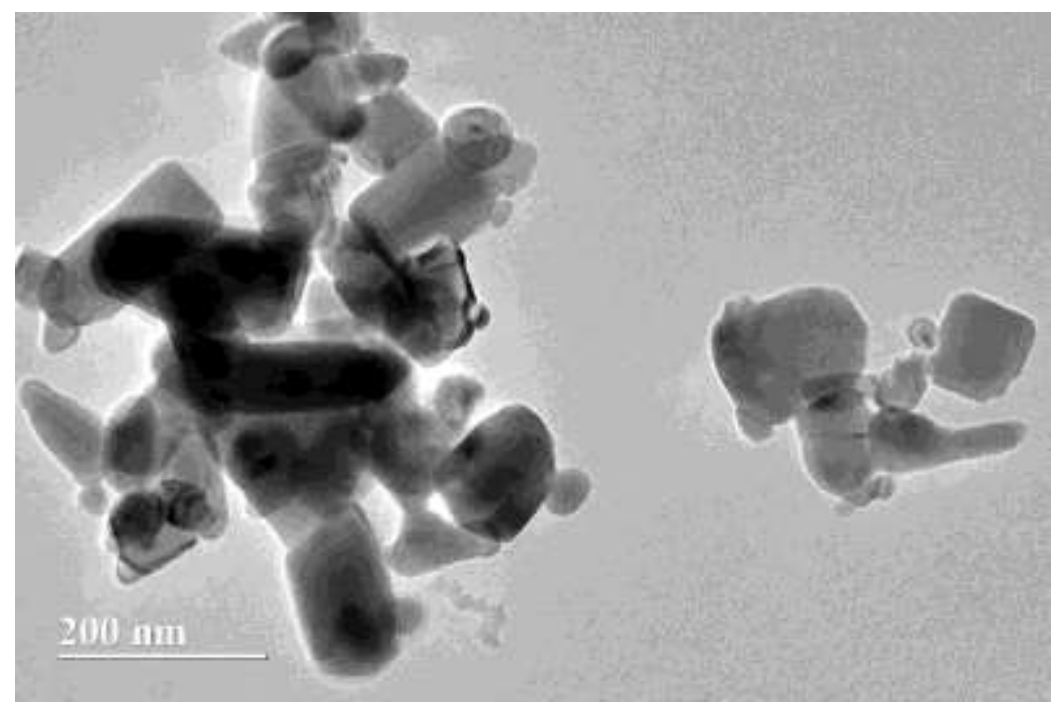

Source: Authors.

\section{Conclusion}

NC films with different ZnO NPs contents were successfully obtained by the solvent casting method. Infrared spectra showed no distinction before and after irradiation of NCs at $140 \mathrm{~Gy}$, indicating that the chemical structure of PCL is preserved. According to the images obtained by scanning electron microscopy, the NPs were randomly dispersed in the polymer matrix. DSC analyses showed marginal variations for the crystallinity content in all analyzed samples. Few studies have been 
performed to elucidate the effect of gamma radiation at a therapeutic dose on PCL and its derivatives. Our results demonstrated that radiation in a therapeutic dose was not able to promote changes in the chemical character of PCL.

Our previous results indicate the need to evaluate the effects of gamma radiation in a therapeutic dose on the thermal, mechanical, morphological and structural properties of polymeric nanocomposites.

\section{References}

Augustine, R., Kalarikkal, N., \& Thomas, S. (2016). Effect of zinc oxide nanoparticles on the in vitro degradation of electrospun polycaprolactone membranes in simulated body fluid. International Journal of Polymeric Materials and Polymeric Biomaterials, 65(1), $28-37$. https://doi.org/10.1080/00914037.2015.1055628

Augustine, R., Malik, H. N., Singhal, D. K., Mukherjee, A., Malakar, D., Kalarikkal, N., \& Thomas, S. (2014). Electrospun polycaprolactone/ZnO nanocomposite membranes as biomaterials with antibacterial and cell adhesion properties. Journal of Polymer Research, 21(3). https://doi.org/10.1007/s10965-013-0347-6

Chang, S. H., Lee, H. J., Park, S., Kim, Y., \& Jeong, B. (2018). Fast Degradable Polycaprolactone for Drug Delivery. Biomacromolecules, 19(6), 2302-2307. https://doi.org/10.1021/acs.biomac.8b00266

Cooke, S. L., \& Whittington, A. R. (2016). Influence of therapeutic radiation on polycaprolactone and polyurethane biomaterials. Materials Science and Engineering C, 60, 78-83. https://doi.org/10.1016/j.msec.2015.10.089

Silva, W. B., Aquino, K. A. D. S., De Vasconcelos, H. M., \& Araujo, E. S. (2013). Influence of copper chloride and potassium iodide mixture in poly(vinyl chloride) exposed to gamma irradiation. Polymer Degradation and Stability, 98(1), 241-245. https://doi.org/10.1016/j.polymdegradstab.2012.10.006

Das, R., Pattanayak, A. J., \& Swain, S. K. (2018). Polymer nanocomposites for sensor devices. Polymer-based Nanocomposites for Energy and Environmental Applications: A volume in Woodhead Publishing Series in Composites Science and Engineering. https://doi.org/10.1016/B978-0-08-102262-7.00007-6

Dwivedi, R., Kumar, S., Pandey, R., Mahajan, A., Nandana, D., Katti, D. S., \& Mehrotra, D. (2020). Polycaprolactone as biomaterial for bone scaffolds: Review of literature. Journal of Oral Biology and Craniofacial Research, 10(1), 381-388. https://doi.org/10.1016/j.jobcr.2019.10.003

Elen, K., Murariu, M., Peeters, R., Dubois, P., \& Mullens, J. (2012). Towards high-performance biopackaging : barrier and mechanical properties of dualaction polycaprolactone/zinc oxide nanocomposites. Polymers Advanced Technologies, 23, 1422-1428. https://doi.org/10.1002/pat.2062

Forster, P. L., Parra, D. F., Lugao, A. B., Kai, J., \& Brito, H. F. (2015). Highly luminescent polycaprolactone films doped with diaquatris(thenoyltrifluoroacetonate)europium(III) complex. Journal of Luminescence, 167, 85-90. https://doi.org/10.1016/j.jlumin.2015.05.041

Labet, M., \& Thielemans, W. (2009a). Synthesis of polycaprolactone: a review. Chemical Society Reviews, 38(12), 3484-3504. https://doi.org/10.1039/B820162P

Lepot, N., Bael, M. K. Van, Rul, H. Van Den, Haen, J. D., Peeters, R., Franco, D., \& Mullens, J. (2010). Influence of Incorporation of ZnO Nanoparticles and Biaxial Orientation on Mechanical and Oxygen Barrier Properties of Polypropylene Films for Food Packaging Applications. Journal of Applied Polymer Science, 120, 1616-1623. https://doi.org/10.1002/app

Lopez-Figueras, L., Navascues, N., \& Irusta, S. (2017). Polycaprolactone/mesoporous silica MCM-41 composites prepared by in situ polymerization. Particuology, 30, 135-143. https://doi.org/10.1016/j.partic.2016.05.005

Lyu, J. S., Lee, J. S., \& Han, J. (2019). Development of a biodegradable polycaprolactone film incorporated with an antimicrobial agent via an extrusion process. Scientific Reports, 9(1), 1-11. https://doi.org/10.1038/s41598-019-56757-5

Mallakpour, S., \& Behranvand, V. (2016). Nanocomposites based on biosafe nano ZnO and different polymeric matrixes for antibacterial, optical, thermal and mechanical applications. European Polymer Journal, 84, 377-403. https://doi.org/10.1016/j.eurpolymj.2016.09.028

Mallakpour, S., \& Nouruzi, N. (2016). Effec of modified ZnO nanoparticles with biosafe molecule on the morphology and physiochemical properties of novel polycaprolactone nanocomposites. Polymer (United Kingdom), 89, 94-101. https://doi.org/10.1016/j.polymer.2016.02.038

Mattioli-Belmonte, M., Vozzi, G., Whulanza, Y., Seggiani, M., Fantauzzi, V., Orsini, G., \& Ahluwalia, A. (2012). Tuning polycaprolactone-carbon nanotube composites for bone tissue engineering scaffolds. Materials Science and Engineering C, 32(2), 152-159. https://doi.org/10.1016/j.msec.2011.10.010

Paula, M., Diego, I., Dionisio, R., Vinhas, G., \& Alves, S. (2019). Gamma irradiation effects on polycaprolactone/zinc oxide nanocomposite films. Polimeros, 29(1), 1-7. https://doi.org/10.1590/0104-1428.04018

Pereira-Loch, C., Benavides, R., Lima, M. F. S., \& Huerta, B. M. (2011). Radiation and thermal effects on polymeric immobilization devices used in patients submitted to radiotherapy. Journal of Radiotherapy in Practice, 11(2), 101-106. https://doi.org/10.1017/S1460396911000124

Stewart, S. A., Domínguez-Robles, J., McIlorum, V. J., Gonzalez, Z., Utomo, E., Mancuso, E., Larrañeta, E. (2020). Poly(caprolactone)-Based Coatings on 3D-Printed Biodegradable Implants: A Novel Strategy to Prolong Delivery of Hydrophilic Drugs. Molecular Pharmaceutics, 17(9), 3487-3500. https://doi.org/10.1021/acs.molpharmaceut.0c00515

Woodruff, M. A., \& Hutmacher, D. W. (2010). The return of a forgotten polymer - Polycaprolactone in the 21 st century. Progress in Polymer Science (Oxford), 35(10), 1217-1256. https://doi.org/10.1016/j.progpolymsci.2010.04.002 